\title{
Studi Pendahuluan: Strategi Promosi Kesehatan Mental Di Lingkungan Kampus Melalui Partisipasi Dosen Wali
}

\author{
Ni Gusti Made Rai ${ }^{1}$, Tony Dwi Susanto ${ }^{2}$, Eka Dian Savitri ${ }^{3}$, Aurelius Ratu ${ }^{4}$ \\ 1,3,4 Departemen Studi Pembangunan, Fakultas Bisnis Manajemen Teknologi, ITS, 60111 \\ ${ }^{2}$ Departemen Sistem Informasi Fakultas Teknologi Informasi dan Komunikasi, ITS, 60111 \\ Email:ni.gusti@its.ac.id ${ }^{1}$
}

Diterima: 30/01/2020

Direview: $29 / 06 / 2020$

Diterbitkan: 30/07/2020

Hak Cipta @ 2020 oleh Penulis (dkk) dan Jurnal

Sosial Humaniora (JSH)

*This work is licensed under the Creative

Commons Attribution International License (CC

BY 4.0).

http://creativecommons.org/licenses/by/4.0/

Open Access

\begin{abstract}
Subject Area: Psychology (Psikologi)
Abstract

In providing qualified, physically, and mentally health graduates, students' mental health should be paid more attention than before. As the mentalhealth affects a person's psychological condition, in this preliminary research, we seek to formulate the strategy in giving a framework for the PDC program. Academic advisors (dosen wali) became participants in this study. We consider them to know better what students need and can realize an effort to prevent mental health problems. The research used qualitative data and the FGD method to gain the data. The results indicated that how academic advisors need student mental health service as part of the academic process, which showed the crucial issues related to college student mental health.
\end{abstract}

Keywords: mental health; academic adviser; student.

\section{Pendahuluan}

Saat ini model pendidikan telah merujuk pada sistem yang menitikberatkan empowering of people, sehingga melalui pendidikan diharapakan dapat meningkatkan kualitas manusia sebagai individu. Bagaimana individu dalam lingkungan kehidupan di perguruan tinggi mampu menggunakan potensi yang dimiliki secara optimal, efisien, dan bahkan mampu berkontribusi di lingkungan sosialnya ditengah tantangan kehidupan. Perguruan tinggi memiliki peran dalam meningkatkan kualitas lulusan. WHO menjadikan kesehatan mental sebagai isu penting, maka dicanangkan gerakan global 2013-2020 dengan empat tujuan utama, yaitu kepemimpinan efektif dan tata kelola untuk kesehatan mental; menyediakan pelayanan kesehatan mental dan pelayanan sosial di masyarakat secara terpadu dan komprehensif; implementasi strategi promosi dan pencegahan, dan penguatan sistem informasi (Karyani, 2016). Dalam hal ini kampus diharapkan memiliki rencana dan implementasi yang mewujudkan adanya kesadaran pentingnya mengurangi persoalan kesehatan mental. Demi tercapainya tujuan pendidikan yaitu mencetak generasi yang tangguh dan berkualitas.

Kesehatan mental menunjukkan adanya kontribusi dari individu dalam aktivitas sosial. WHO menjelaskan dari sudut pandang positif bahwa kesehatan mental menjadi masalah mendasar untuk tercapainya suatu kondisi wellbeing dan efektifitas manusia dalam menggunakan kapasitas dirinya secara optimal. Menurut WHO, kesehatan mental adalah kondisi kesejahteran mental individu yang mampu menggunakan kapasitas dirinya secara optimal termasuk dalam menghadapi situasi stres dalam kehidupan, mampu berkerja secara efisien, dan mampu memberikan kontribusi positif di lingkungannya (Smith \& Myriam, 2013). Menurut WHO 
kesehatan mental bukan sekedar bebasnya dari kondisi sakit mental, yaitu mengenai kesejahteraan manusia yang mana individu menyadari potensi yang dimiliki, dalam kehidupan normal mampu mengatasi stres secara umum, dapat bekerja secara produktif dan optimal, dapat memberikan kontribusi di lingkungannya (Kermode et al., 2007). Kesehatan mental disebut juga sebagai kondisi mental dan emosional individu yang dapat memengaruhi seseorang untuk menunjukkan perilaku efektif di lingkungan dan mencapai tujuan serta mengembangkan kepribadian (Wojda-kornacka, 2016). Untuk mewujudkan kesehatan mental berarti perlu melakukan upaya strategis dengan menyusun program promosi sebagai usaha preventif.

Berdasarkan WHO bahwa promosi kesehatan mental merupakan suatu kegiatan untuk menciptakan kondisi lingkungan yang mendukung dan mengijinkan individu melakukan penyesuaian gaya hidup yang sehat (Reilly, Svirydzenka, Adams, \& Dogra, 2018). WHO menjelaskan bahwa kebijakan kesehatan mental meliputi promosi kesehatan mental dan tidak terbatas pada sektor kesehatan, tetapi juga pendidikan, pekerjaan, peradilan, tranportasi, lingkungan,dll (O’Reilly, 2018). Promosi kesehatan mental di lingkungan kampus menggunakan pendekatan sistem atau organisasi sehingga membutuhkan keterlibatan berbagai sektor. Promosi kesehatan mental juga meliputi keseluruhan yang mencakup organisasi di sekolah atau kampus sebagai level yang tertinggi mulai dari kepala sekolah hingga pegawai. Selanjutnya pihak yang terlibat tidak hanya dosen dan mahasiswa melainkan pemimpin selaku pengambil kebijakan. Di sektor yang promosi kebijakan juga meliputi kurikulum pendidikan yang disusun. Pada akhirnya bahwa layanan kesehatan mental ditujukan kepada mereka yang memiliki kecenderungan membutuhkan support sebelum terjadinya masalah berarti. Hingga di level akhir, yaitu pelayanan kesehatan mental ditujukan kepada mahasiswa yang memiliki masalah (Smith \& Myriam, 2013).

Mahasiswa di perguruan tinggi merupakan sekelompok individu yang memiliki karakteristik pribadi berdasarkan usia transisi yang memiliki beberapa ciri yang menantang. Berdasarkan usia yang sebagian besar di bawah 24 tahun memiliki presentase kesehatan yang memungkinkan perlu datang ke unit konseling (Macaskill, 2013).. Selain itu menurut Kermode, (Kermode et al., 2007) bahwa kampus juga dapat menjadi sumber stres karena terdapat beragam kompetisi dan persaingan sosial. Bahkan menurut Douce (2014), keberhasilan yang diraih di sepanjang masa pendidikan tinggi akan memengaruhi kehidupan dan karir, sehingga mahasiswa perlu menyiapkan diri untuk belajar. Adanya kondisi masalah kesehatan mental seperti stres, cemas dan depresi serta gangguan lainnya tentu akan memengaruhi kualitas dan kuantitas mahasiswa untuk melakukan aktivitas akademik. Lebih lanjut kondisi mahasiswa dengan masalah kesehatan mental akan menurunkan kapasitas dan fleksibilitas fungsi kognitif dan emosional yang mempengaruhi kemampuan kreatif dan kesiapan menghadapi informasi dan tantangan baru (Douce et al., 2014). Menurut Skolowska, mahasiswa sebagai individu yang berada di tahap awal memasuki beragam perubahan akan menghadapi banyak variasi masalah psikologis, jika tidak siap dengan coping stress. Terdapat pula data dari survey yang dilakukan untuk mendeteksi risiko bunuh diri di kampus ITS, diketahui bahwa tedapat kecenderungan mahasiswa dengan risiko bunuh diri. Hingga saat ini juga ditemui adanya mahasiswa depresi sehingga mempengaruhi proses kuliahnya. 
Penelitian ini berfokus bagaimana posisi dosen wali sebagai pendamping dalam mendukung kualitas kesehatan mental mahasiswa sebagai upaya kegiatan promosi kesehatan mental. Harapannya dengan keberadaan dosen wali yang optimal akan menjadi support sosial bagi mahasiswa yang sedang berkembang di lingkungan kampus. Hal ini menunjukkan adanya peran yang mendukung peningkatan kualitas dan kompetensi life skill mahasiswa. Dalam rangka mewujudkan harapan tersebut, diperlukan adanya penggalian informasi dari sudut pandang dosen wali yang mendampingi mahasiswa dalam upaya promosi kesehatan mental di lingkungan kampus (Smith \& Myriam, 2013).

Memberikan proteksi dan promosi kesehatan mental kepada mahasiswa sebagai generasi muda akan memberikan kontribusi positif dalam membangun kesiapan menghadapi tantangan perkembangan (Wojdakornacka, 2016). Kesadaran akan pentingnya promosi kesehatan mental perlu semakin ditingkatkan untuk mencapai kualitas mahasiswa yang lebih optimal. Dalam rangka mewujudkan harapan tersebut perlu adanya langkah penetapan strategi promosi yang efektif. Untuk itu tentu diperlukan adanya keterlibatan semua pihak, yaitu stakeholder di lingkungan kampus, meliputi pimpinan selaku pengambil kebijakan, dosen dan dosen wali serta mahasiswa (Dunne \& Somerset, 2004).

Banyak universitas atau perguruan tinggi di Amerika, Inggris, Wales dan Scontland telah mengeluarkan program promosi kesehatan mental dengan melakukan program-program yang sesuai dengan kebutuhan dan peningkatan kualitas kesehatan mental mahasiswa ataupun di lingkungan sekolah (Douce et al., 2014). Besar harapan adanya suatu rancangan strategi promosi kesehatan mental di lingkungan kampus untuk menetapkan serangkaian upaya prevensi. Dibutuhkan adanya kesadaran yang tinggi tentang isu kesehatan mental khususnya di lingkungan kampus yang banyak memiliki program studi teknikS ebagai langkah awal diperlukan adanya partisipasi termasuk dosen wali, bagaimana sudut pandang persetujuan terhadap layanan kesehatan mental mahasiswa, bagaimana harapan peningkatkan ketrampilan dosen wali untuk menunjang kualitas kesehatan mental mahasiswa, bagaimana isu problem mahasiswa sebagai tekanan yang mempengaruhi kualitas kesehatan mental, bagaimana rekomendasi program promosi kesehatan mental.

\section{Tinjauan Pustaka}

Promosi kesehatan mental merupakan suatu gerakan yang meningkatkan kesadaran banyak pihak terkait kesehatan mental. Sebagai strategi yang dapat menciptakan dan meningkatkan kualitas kesehatan mental. Menurut WHO promosi kesehatan mental merupakan suatu kegiatan untuk menciptakan kondisi lingkungan yang mendukung dan mengijinkan individu melakukan penyesuaian gaya hidup yang sehat (Reilly et al., 2018). Status kesehatan mental menunjukkan suatu kondisi yang mempengaruhi keefektifan dan produktifitas seorang individu bagi diri maupun bagi lingkungan. Promosi kesehatan mental secara mendasar adalah tindakan yang memfasilitasi lingkungan untuk memiliki sikap respek terhadap masalah kesehatan mental. WHO menjelaskan bahwa kebijakan kesehatan mental meliputi promosi kesehatan mental dan tidak terbatas pada sektor kesehatan, tetapi juga pendidikan, pekerjaan, peradilan, tranportasi, lingkungan,dll (O’Reilly, 2018). 
Kesehatan mental yang merupakan kondisi kesejahteraan mental individu menjadi isu penting. Bahwa kesejahteraan individu tercapai jika menyadari potensinya dan mamppu mengatasi stress pada umum dan dapat bekerja secara optimal. Selain itu menurut WHO kesehatan mental bukan sekedar bebasnya dari kondisi sakit mental, yaitu mengenai kesejehteraan manusia yang mana individu menyadari potensi yang dimiliki, dalam kehidupan normal mampu mengatasi stres secara umum, dapat bekerja secara produktif dan optimal, dapat memberikan kontribusi di lingkungannya (Kermode et al., 2007).

Dosen wali sebagai pembimbing akademik memiliki tugas melakukan perwalian terhadap mahasiswa dalam menghadapi berbagai macam persoalan (Dikti, 2001). Dosen wali disini bukan dosen pembimbing akademik tugas akhir yang melakukan pembinaan terhadap proses penyelesaian skripsi. Dosen wali yang menjadi pembimbing mahasiswa sejak menjadi mahasiswa baru ditahun pertama. Biasanya agenda dosen wali bertemu dengan mahasiswa bimbingan dilakukan pada saat perwalian. Berdasarkan surat edaran Dikti, 2001 disebutkan dosen wali dapat mengalokasikan waktu satu jam perminggu untuk melakukan perwalian. Mahasiswa dapat melakukan konsultasi mengenai kesulitan selama menjalani perkuliahan dan tidak terbatas pada masalah yang ditemui pada mata kuliah yang sedang ditempuh. Dengan demikian dosen wali memiliki keterlibatan yang cukup untuk dapat melihat perkembangan kondisi mahasiswa. Khusunya bagi mahasiswa yang memiliki masalah kompleks maka dapat menemui dosen wali dalam rangka mencari solusi atas permasalahan yang dihadapi.

\section{Metode Penelitian}

Penelitian ini merupakan penelitian pendahuluan dalam rangka menentukan rumusan kebijakan mahasiswa sehubungan dengan kesehatan mental guna mewujudkan kualitas lulusan di lingkungan kampus ITS. Penelitian ini merupakan penelitian kualitatif, menggunakan Focused Groups Disscussion (FGD) sebagai metode pengumpulan data. FGD menjadi salah satu alternatif pilihan untuk menggali data kualitatif dengan memanfatkan dinamika kelompok sebagai stimulasi diskusi sesuai topik yang ditentukan (Dunne \& Somerset, 2004). Pope dan Mays (1995) menyatakan, metode kualitatif adalah metode yang sesuai untuk mengembangkan konsep secara induktif yang alami. Dari obervasi hingga penyusunan suatu hipotesis. Phillips-Morrow (2000) juga menambahkan, hasil dari FGD dapat dikembangkan rekomendasi praktis dan menjadi usulan yang tepat dalam menyusun strategi promosi kesehatan mental sesuai dengan isu yang sedang berkembang, termasuk dalam kehidupan kampus. Selain mengumpulkan data melalui FGD, penelitian ini juga menggunakan data sekunder berupa kuesioner survey yang diberikan kepada dosen wali. Sebagai wujud tambahan informasi dalam mengembangkan usulan rekomendasi promosi kesehatan di kampus.

\section{Partisipan}

Partisipan dalam penelitian ini adalah dosen wali ITS, yang terdiri atas 20 orang dosen wali dari 38 dosen wali yang ditargetkan. Partisipan adalah pihak yang bersedia terlibat penuh dan mengikuti jalannya FGD sejak awal kegiatan hingga diperoleh simpulan kelompok. Total waktu yang diperlukan adalah 60 menit. Partisipan merupakan dosen wali yang memiliki perhatian kepada pengembangan mahasiswa. 
Topik diskusi FGD, meliputi:

1) Bagaimana kebutuhan akan layanan untuk mahasiswa guna mendukung kualitas kesehatan mental?

2) Bagaimana pengembangan kompetensi dosen wali untuk mendukung peningkatan kualitas kesehatan mental mahasiswa?

3) Bagaimana permasalahan atau isu yang diketahui oleh dosen wali sehubungan dengan masalah kesehatan mental mahasiswa?

4) Bagaimana saran yang dapat diusulkan sebagai bentuk program promosi kesehatan mental?

\section{Hasil Penelitian dan Pembahasan}

\section{Sudut pandang Dosen Wali terhadap Pelayanan Kesehatan Mental Mahasiswa}

Partisipan yang hadir dalam kegiatan FGD berjumlah 20 dosen yang berasal dari 15 departemen. Partisipan diminta memberi argumen tentang perlu/tidaknya ITS menyediakan layanan kesehatan mental terutama bagi mahasiswa. Hasil diskusi tersebut dapat dilihat pada tabel 1.

Tabel. 1. Partisipan Utama dalam kegiatan FGD

\begin{tabular}{lcc}
\hline Asal Departemen/ Fakultas & Jumlah & $\begin{array}{c}\text { Pelayanan kesehatan mental } \\
\text { (Setuju/ tidak setuju) }\end{array}$ \\
\hline Biologi & 2 & Setuju \\
Informatika & 1 & Setuju \\
FTLSK & 1 & Setuju \\
DTISF & 1 & Setuju \\
Soshum & 1 & Setuju \\
Perkapalan & 1 & Setuju \\
Desain Produk & 1 & Setuju \\
Sistem Infomasi & 2 & Setuju \\
Arsitektur & 1 & Setuju \\
DTP & 1 & Setuju \\
Material & 1 & Setuju \\
Matematika & 1 & Setuju \\
Kimia Industri & 1 & Setuju \\
NN & 5 & Setuju \\
\hline
\end{tabular}

Sumber: data peneliti, 2019

Tabel 1 menunjukkan seluruh partisipan menyatakan setuju dengan disediakannya pelayanan kesehatan mental di kampus. Hal ini sebagai salah satu solusi peningkatan kualitas kesehatan mental mahasiswa. Terdapat 16 partisipan yang menyatakan ada kebutuhan membuat unit tertentu yang dapat mengakomodasi kebutuhan masalah mahasiswa.

"Saya rasa, perlu ada unit yang melayani permasalahan psikologis mahasiswa, selain di unit medical centre. Soalnya adanya persepsi sakit saat datang ke "medical centre" membuat mahasiswa menjadi kurang nyaman. akhirnya tidak dapat menyelesaikan persoalan."

Keterlibatan peran dosen wali sebagai pembimbing mahasiswa juga mendukung tercapainya kualitas pribadi yang lebih positif. Selain itu juga dijelaskan bahwa sebagian besar dari dosen pendamping 
menginginkan adanya hubungan pertemanan dengan mahasiswa baru dalam rangka menlakukan pendekatan (Chan, 2016).

\section{Pengembangan kompetensi dosen wali untuk menunjang kualitas kesehatan mental mahasiswa:}

Ada 12 dosen yang menyatakan diperlukan pelatihan teknik konseling kepada dosen wali, agar dapat memberikan pelayanan terdepan dengan teknik konseling sederhana kepada mahasiswa wali yang membutuhkan perhatian. Dosen wali memiliki harapan dapat memberikan kontribusi kepada mahasiswa secara tepat, misalnya mampu memberikan dukungan saat mahasiswa mengalami penurunan semangat belajar. Para dosen wali ingin berperan aktif. Mereka ingin mengetahui dan mengenali teknik untuk mengidentifikasi masalah mahasiswa; dosen wali membutuhkan adanya peningkatan ketrampilan komunikasi dan motivatsi untuk menghadapi mahasiswa. Meski demikian beberapa dosen belum tau dan tidak mengenali langkah yang harus dilakukan kemudian untuk membantu mahasiswa. Berdasarkan hasil diskusi dapat disimpulkan bahwa isu problem pada mahasiswa sebagai tekanan yang mempengaruhi kualitas kesehatan mental ada 4 yaitu masalah akademik, masalah sosial, masalah keluarga, masalah perilaku.

\section{Masalah Akademik}

Secara umum persoalan akademik dianggap menjadi masalah yang menjadi sumber tekanan pada mahasiswa. Banyaknya tugas yang dibebankan kepada mahasiswa; ketakutan pada mata kuliah sejak awal; kurang dan hilangnya motivasi karena beban terhadap mata kuliah yang tidak disukai; merasa kehilangan motivasi karena teman lulus lebih dahulu; ketidakcocokan dengan dosen pembimbing; merasa salah pilih jurusan; persoalan TA yang tidak kunjung selesai; bolos (pelanggaran akademik). Salah satu persoalan yang sering dihadapi adalah adanya pengalaman gagal atau nilai turun sehingga kesulitan meningkatkan prestasi selanjutnya. Pengalaman mendapatkan nilai yang tidak sesuai harapan ternyata membuat mahasiswa merasa tertekan. Hal ini menjadi masalah yang kemudian berlanjut pada studi berikutnya. Mahasiswa membutuhkan penyesuaian yang lebih lama terkait pengalaman mendapati nilai yang di luar harapannya.

"Ketika mahasiswa nilainya turun dan merasa gagal, itu jadi salah satu yang menghambat jalannya studi selanjutnya."

Masalah Tugas Akhir juga sering kali menjadi topik tekanan bagi mahasiswa. Terutama jika penyelesaian tugas akhir membutuhkan waktu lama. Belum lagi jika adanya ketidakcocokan dengan dosen pembimbing. Persoalan akademis juga terkait dengan adanya relasi yang terbangun antara mahasiswa dan dosen pembimbing. Hingga berdampak pada terhambatnya kegiatan perkuliahan lebih lanjut hingga mempengaruhi masa studi. Berkaitan pula dengan penyelesaian tugas akhir yang menjadi lebih panjang.

\section{Penyesuaian Sosial}

Penyesuaian sosial terjadi saat mahasiswa menjalani kehidupan di kampus yang berkaitan dengan teman seangkatan, kakak tingkat, dosen maupun pihak lainnya. Dosen wali seringkali menangkap adanya ketrampilan sosial mahasiswa awalnya mempengaruhi bagaimana penyesuaian sosialnya. Ketrampilan sosial 
yang kurang seperti tidak mengenal sopan-santun, ketrampilan dalam menampilkan etika dan komunikasi akan membuat adanya jarak terhadap orang lain terutama pihak lain yang lebih tua. Pola kepribadian seperti lebih banyak menarik diri akan membuat kesempatan lebih sedikit dalam melakukan penyesuaian.

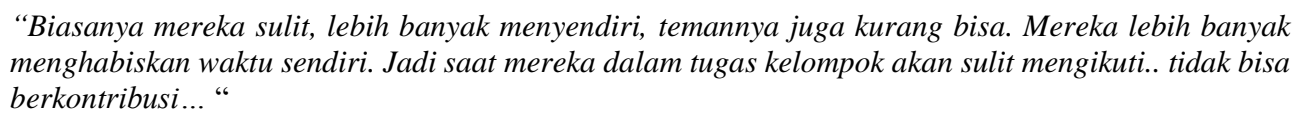

Dan lebih lanjut akan muncul perasaan sedih dalam waktu yang lebih panjang. Kemampuan untuk memulai relasi dalam suatu tim akan membuat adanya kesulitan penyesuaian. Mahasiswa menjadi sulit untuk berkontribusi dalam tim dan kurang mendapat peranan yang diharapkan oleh pihak lain. Atau sebaliknya, terdapat persepsi dosen wali dengan keiikutsertaan dalam organisasi yang terlalu aktif menimbulkan kesulitan dalam penyesuaian sosial.

\section{Masalah Keluarga}

Berkaitan dengan masalah keluarga, dosen wali lebih banyak berpendapat mengenai adanya masalah keharmonisan keluarga yang kurang. Mahasiswa dengan latar belakang keluarga yang kurang harmonis mendapatkan adanya perasaan kurang nyaman. Selain itu, adanya tuntutan dan tekanan dari orang tua terhadap anak juga menjadi hal yang diamati oleh dosen wali sebagai problem sehingga membuat mahasiswa memiliki masalah. Adanya kondisi ekonomi yang kurang juga juga salah satu problem. Kurangnya dukungan emosional selama perkuliahan menurut dosen wali menjadi problem yang membuat mahasiswa merasa kurang mantap secara mental.

"Keluarga yang kurang harmonis... broken home jadi seperti ini.."

\section{Masalah perilaku}

Berkaitan dengan masalah perilaku yang muncul sebagai problem dari adanya persoalan yang menyebabkan perhatian lebih bagi dosen wali, juga muncul seperti adanya kecenderungan bolos pada jam mata kuliah, jumlah ketidakhadiran yang melebihi batas akan menjadi masalah. Mahasiswa yang dianggap melakukan pelanggaran terhadap aturan akan menghadapi masalah lebih lanjut, dan juga dianggap sebagai awal dari permasalahan. Adanya anggapan bahwa banyaknya aktivitas berkaitan dengan game atau komik online serta penggunaan media sosial yang berlebihan juga menjadi bagian dari masalah yang ada. Bahkan lebih lanjut, adanya pandangan dipengaruhi adanya aktvitas yang berhubungan dengan masalah seks melalui tontonan berupa pornografi (video porno).

\footnotetext{
"Beberapa juga ada yang sering bolos sehingga menjadi awal dari kesulitannya menempuh kuliah. tugas-tugas yang banyak. ......Anak-anak itu menonton vidoe, kecanduan seks pornografi, game online, dan juga ikut judi online."
}

Beragam persoalan mahasiswa tersebut menjadi masukan bagi konsep desain strategi layanan kesehatan mental bagi mahasiswa di ITS. Berikut ini adalah desain isu problem mahasiswa serta bagaimana cara menanganinya. 


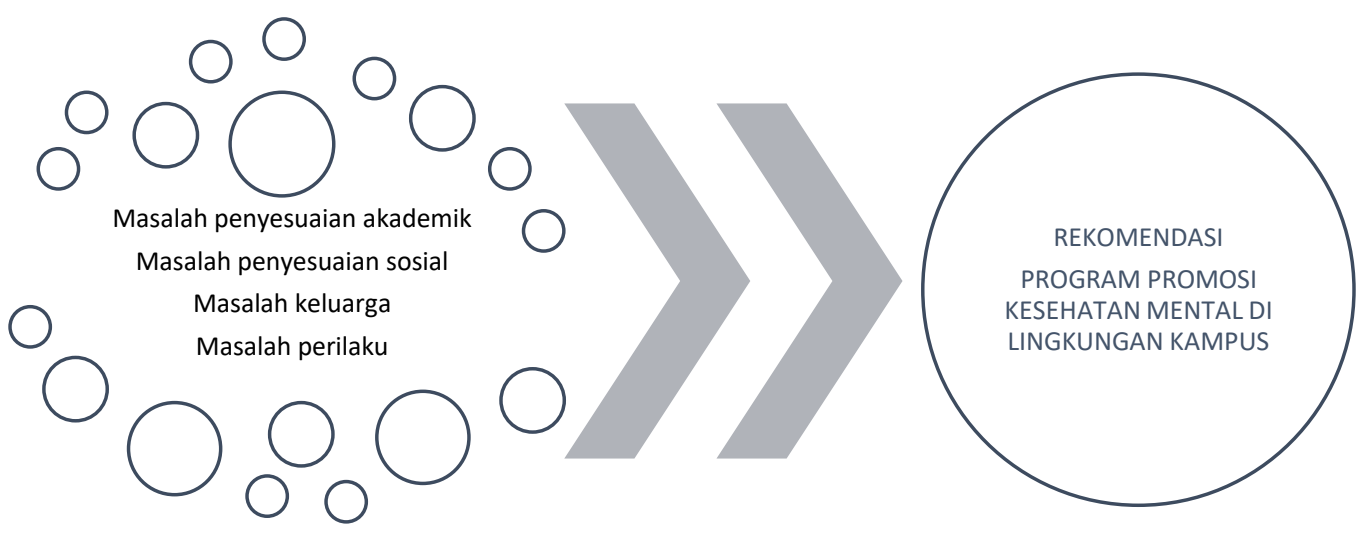

Keempat isu masalah mahasiswa yang diperoleh dari hasil FGD merupakan identifikasi awal persoalan mahasiswa di ITS. Untuk mengatasi hal tersebut, diperlukan langkah awal penanganan berupa program promosi kesehatan mental. Pada diskusi di awal, diketahui bahwa dosen wali berharap agar ITS menyediakan layanan kesehatan bagi para mahasiswa. Dosen wali memberi masukan tidak hanya berisi berbagai macam persoalan mahasiswa namun juga berbagai rekomendasi berdasarkan pengalaman mereka dalam menangai mahasiswa. Oleh karena itu, peneliti menyusun desain program promosi kesehatan mental mahasiswa berdasarkan rekomendasi dari dosen wali yang disajikan pada gambar 2.

Gambar 2. Rekomendasi program promosi kesehatan mental mahasiswa dari dosen wali

\begin{tabular}{|c|c|c|c|}
\hline $\begin{array}{l}\text { Peningkatan Kompetensi } \\
\text { Dosen wali : } \\
\text { - Mendapatkan pelatihan } \\
\text { konseling } \\
\text { - Mendapatkan Guidence } \\
\text { penanganan mahasiswa } \\
\text { - Diadakan pembekalan secara } \\
\text { berkala untuk dosen wali } \\
\text { - Dosen wali perlu mengenali } \\
\text { kebutuhan mahasiswa }\end{array}$ & $\begin{array}{l}\text { Prograr } \\
\text { Kesehata } \\
\text { lingkung }\end{array}$ & $\begin{array}{l}\text { nosi } \\
\text { impul di } \\
\text { impus }\end{array}$ & $\begin{array}{l}\text { Peningkatan Kompetensi } \\
\text { Mahasiswa } \\
\text { - Mahasiswa mendapatkan } \\
\text { pengenalan dunia kampus } \\
\text { saat awal "Maba" } \\
\text { (mahasiswa baru) } \\
\text { - Memberikan pelatihan } \\
\text { kepada mahasiswa seperti: } \\
\text { manajemen stress. }\end{array}$ \\
\hline $\begin{array}{l}\text { Sistem Layana } \\
\text { - Membuat SOP per } \\
\text { menambahkan cek } \\
\text { mahasiswa } \\
\text { - Memasukkan mate } \\
\text { Pelatihan wajib ba } \\
\text { - Membuat SOP unt } \\
\text { bermasalah sebaga } \\
\text { ke orang tua } \\
\text { - Membuat SOP, ter } \\
\text { Mahasiswa-Orang } \\
\text { - Membentuk TIM k } \\
\text { kemahasiwaan } \\
\text { - Diperlukan psikote } \\
\text { baru. }\end{array}$ & $\begin{array}{l}\text { g: } \\
\text { n } \\
\text { dalam } \\
\text { a } \\
\text { mative } \\
\text { n Dosen- } \\
\text { iswa }\end{array}$ & $\begin{array}{r}\text { Rewa } \\
\text { - Dite } \\
\text { bag } \\
\text { - Mei } \\
\text { wal } \\
\text { nila }\end{array}$ & $\begin{array}{l}\text { Dosen wali: } \\
\text { stem reward } \\
\text { i } \\
\text { a nama dosen } \\
\text { bar transkip }\end{array}$ \\
\hline
\end{tabular}


Program promosi kesehatan mental di lingkungan kampus perlu didesain sejalan untuk peningkatan kualitas kesehatan mental. Usulan mengenai rekomendasi kebijakan akan menyesuaikan dengan kebutuhan dari masing-masing kampus sebagai institusi pendidikan. Hal ini juga dijelaskan dalam penelitian Hall, bahwa promosi kesehatan mental melibatkan pendekatan organisasi kampus secara menyeluruh dan tertanam secara melekat (Marshall, L. \& Morris, 2015).

Berdasarkan penelitian ini diperoleh adanya persetujuan dari kebutuhan pelayanan kesehatan mental dari seluruh partisipan sebagai harapan yang perlu diwujudkan. Berawal dari persetujuan sebagai harapan dosen wali terhadap kebutuhan tersebut akan mendukung program strategi kesehatan mental di lingkungan kampus (Wojda-kornacka, 2016). Meskipun tidak seluruh partisipan menyebutkan usulan secara spesifik. Masih ada partisipan yang belum mampu menyampaikan kebutuhan program yang dapat mendukung peningkatan kesehatan mental mahasiswa. Namun jumlah partisipan yang mampu menyebutuhkan kebutuhan sebagai harapannya tersebut jumlahnya lebih tinggi.

Adanya isu problem pada mahasiswa sebagai tekanan yang mempengaruhi kesehatan mental, seperti: masalah akademik, masalah sosial, keluarga dan masalah perilaku. Masalah akademik berkaitan dengan bidang keahlian atau jurusan yang sedang ditempuh. Sebagai mahasiswa terutama saat melalui masa tahun pertama tentunya membutuhkan banyak informasi terkait bidang yang akan dipelajari. Jika adanya beban yang terlalu berat karena tugas dan kurangnya minat terhadap bidang ilmu sebagai contoh permasalah yang mampu menekan mahasiswa secara berkepanjangan maka akan mempengaruhi proses belajarnya. Hal ini menjadi siklus sehingga berhubungan dengan kesehatan mental (Douce et al., 2014). Fowler juga menyebutkan bahwa kondisi kesehatan mental yang optimal juga mendukung terhadap aktivitas belajar, sosial, dan berkurangnya perilaku menyimpang (Smith \& Myriam, 2013). Masalah keluarga yang terjadi sebelum individu menjadi mahasiswa juga dapat mempengaruhi kondisi kesehatan mental. Keluarga merupakan sistem sosial terkecil dimana membentuk suatu aktivitas yang memungkinkan anggotanya beriteraksi. Masalah dalam keluarga yang berkepanjangan dapat menjadi tekanan tersendiri, dan dapat mempengaruhi kesehatan mental (WHO, 2004).

Peningkatan ketrampilan dan kompetensi bagi dosen wali menjadi salah satu strategi promosi kesehatan mental di lingkungan kampus. Dosen wali merupakan salah satu stakeholder yang perlu mendapatkan adanya pengetahuan tambahan untuk dapat mendukung adanya peningkatan kualitas kesehatan mental mahasiswa. Peran dan fungsi dosen wali telah diatur dalam kurikulum sebagai salah satu penunjang pengembangan kualitas mahasiswa. Melalui kegiatan FGD dalam penelitian ini diperoleh bahwa peningkatan ketrampilan bagi dosen wali diharapkan meliputi adanya tambahan pengetahuan mengenai teknik konseling kepada mahasiswa menjadi salah satu target utama. Dosen wali berharap mengetahui pendekatan yang digunakan kepada mahasiswa terutama saat menghadapi kesulitan khususnya situasi yang menimbulkan perasaan menekan. Adanya kebutuhan peningkatan peranan dalam menjalankan tugas sebagai wujud rasa tanggung jawab dan optimalisasi dalam bertugas. Selain itu dalam menjalankan perananya dosen wali membutuhkan adanya langkah-langkah tertulis sebagai guidance, hal ini dianggap dapat memudahkan jika adanya persoalan yang muncul saat melakukan bimbingan atau konsultasi kepada mahasiswa. Selain itu 
diharapkan adanya pembekalan secara berkala sebagai persiapan awal setiap semester dalam melakukan penugasan. Lebih lanjut adanya usulan dosen wali perlu mendapati karakteristik mahasiswa saat ini sebagai usaha untuk mengenali kebutuhan mahasiswa. Berdasarkan penelitian terdahulu menyebutkan bahwa mahasiswa yang membutuhkan layanan kesehatan mental akan membutuhkan tanggapan dan dukungan yang lebih besar. Hal ini ditunjukkan dengan adanya konsekuensi bahwa dosen wali atau pendamping membutuhkan lebih banyak pelatihan untuk menambahkan kualitas sumber daya lebih lanjut (Wenham, Valencia-Forrester, \& Backhaus, 2019).

Secara umum peningkatan kompetensi bagi dosen wali merupakan salah satu strategi yang perlu dilakukan. WHO menjelaskan, bahwa terdapat salah satu pendekatan yang diperlukan sebagai upaya strategi peningkatan kualitas kesehatan mental siswa, dengan memberikan pengetahuan kepada guru dan orang tua. Pengetahuan yang diberikan kepada guru dan orang tua menjadi salah satu tahap level intervensi yang perlu dilakukan (Smith \& Myriam, 2013). Adanya relasi antara dosen wali dan mahasiswa dapat mendukung hubungan yang positif bagi mahasiswa mengembangkan ketrampilan kehidupan dan hubungan dalam keluarga serta sekolah (Chan, 2016). Selanjutnya, bahwa diakui pula adanya peran dosen wali sebagai pendukung mahasiswa dengan permasalahan terkait kesehatan mental. Pelatihan-pelatihan yang memberikan wawasan dibutuhkan sebagai cara terbaik untuk mendukung mahasiswa dengan permasalahan yang kompleks (Wenham et al., 2019). Sehingga pentingnya dukungan dosen wali sebagai dosen pendamping dalam menumbuhkan persepsi mahasiswa terhadap kepribadian yang positif di kampus. Dosen wali sebagai pendamping memainkan peran yang signifikan untuk mengkoordinasi mahasiswa demi mencapai kualitas personal yang lebih baik dan secara akademik dan bahkan mencapai sikap profesional dalam tujuan perencanaan karir di masa depan (Chan, 2016).

Peningkatan kompetensi kepada mahasiswa dalam penelitian ini muncul sebagai rekomendasi dari dosen wali untuk mendukung tercapainya kualitas kesehatan mental yang lebih baik. Dengan diperolehnya informasi mengenai penyesuaian dunia kampus di awal perkuliahan menjadi saran utama mengenai stratgei penyesuaian yang perlu dilakukan. Apalagi dengan mendapatkan adanya pelatihan yang mengajarkan teknik secara khusus untuk menurunkan tingkatkan stress semasa menjadi mahasiswa. Hal ini sejalan dengan penelitian yang dilakukan Conley, dkk yang menyebutkan adanya fungsi yang penting bagi mahasiswa setelah mendapatkan berbagai penelitian untuk mendukung peningkatan kualitas kesehatan mentalnya (Conley, Durlak, \& Dickson, 2013). Selain mahasiswa membutuhkan pengetahuan mengenai kesehatan mental melalui kegiatan promotif karena diangga sebagai bagian dari kelompok masyarakat yang berpendidikan (Wojdakornacka, 2016).

Diperlukan adanya sistem layanan pendukung untuk melengkapi adanya kebutuhan yang dimiliki oleh mahasiswa dalam meningkatkan kualitas kesehatan mental. Mahasiswa membutuhkan adanya pelayanan untuk menjaga kualitas psikologis dan kesehatan mental dalam menempuh pendidikan terbaik serta meningkatkan rasa percaya diri hingga memasuki peran selanjutnya di dunia kerja (Macaskill, 2013). Dalam mewujudkan kesepakatanan nantinya, dapat melibatkan pihak-pihak seperti pemimpin selaku pembuat kebijakan hingga 
unit-unit dan pihak-pihak lain secara praktis di kampus. Sistem layanan pendukung diharapkan dapat meningkatkan adanya peran stakeholder internal khususnya (Marshall, L. \& Morris, 2015). Berdasakan penelitian yang pernah dilakukan, menunjukkan adanya penanganan awal terhadap masalah psikologis akan memiliki peran yang penting. Mahasiswa harapannya dapat lebih mudah mengakses layanan kesehatan mental (Macaskill, 2013). Dengan penelitian yang banyak dilakukan adanya kecenderungan persoalan yang kompleks pada mahasiswa, sehingga kampus dapat menjadi tempat yang baik untuk membantu mencapai kondisi yang lebih baik untuk mencapai kesuksesan (Hunt \& Eisenberg, 2010). Bahkan dijelaskan selanjutnya bahwa kampus pada akhirnya memerlukan kerjasama dengan pihak layanan pemerintah atau lainnya yang dapat membantu pelayanan kesehatan mental dan mendukung kemudahan akses bagi mahasiswa. (Macaskill, 2013).

Penelitian ini menghasilkan informasi mengenai kebutuhan sistem layanan pendukung, yang meliputi adanya pembuatan alur atau SOP mengenai perwalian, hal ini mendukung adanya tambahan langkah-langkah strategis yang bisa memuat kebutuhan mahasiswa dalam mendapatnya pemetaan awal mengenai masalah yang dimiliki. Jika adanya peningkatan dari layanan oleh dosen kepada mahasiswa yang terintergasi dalam sistem harapannya akan mewujudkan tercapainya peningkatan kualitas kesehatan mental. Lebih lanjut, adanya usulan mengenai pembuatan SOP yang memuat informasi lanjutan kepada orang tua, nantinya dapat menjadi sistem yang lebih kuat. Program promosi kesehatan mental di lingkungan kampus nantinya tidak saja ditujukan pada dosen wali tetapi juga melibatkan seluruh lingkungan kampus, yaitu dalam level yang tertinggi (Dunne \& Somerset, 2004).

Gambar 3. Model komprehensif pendekatan Strategi promosi kesehatan mental di lingkungan kampus

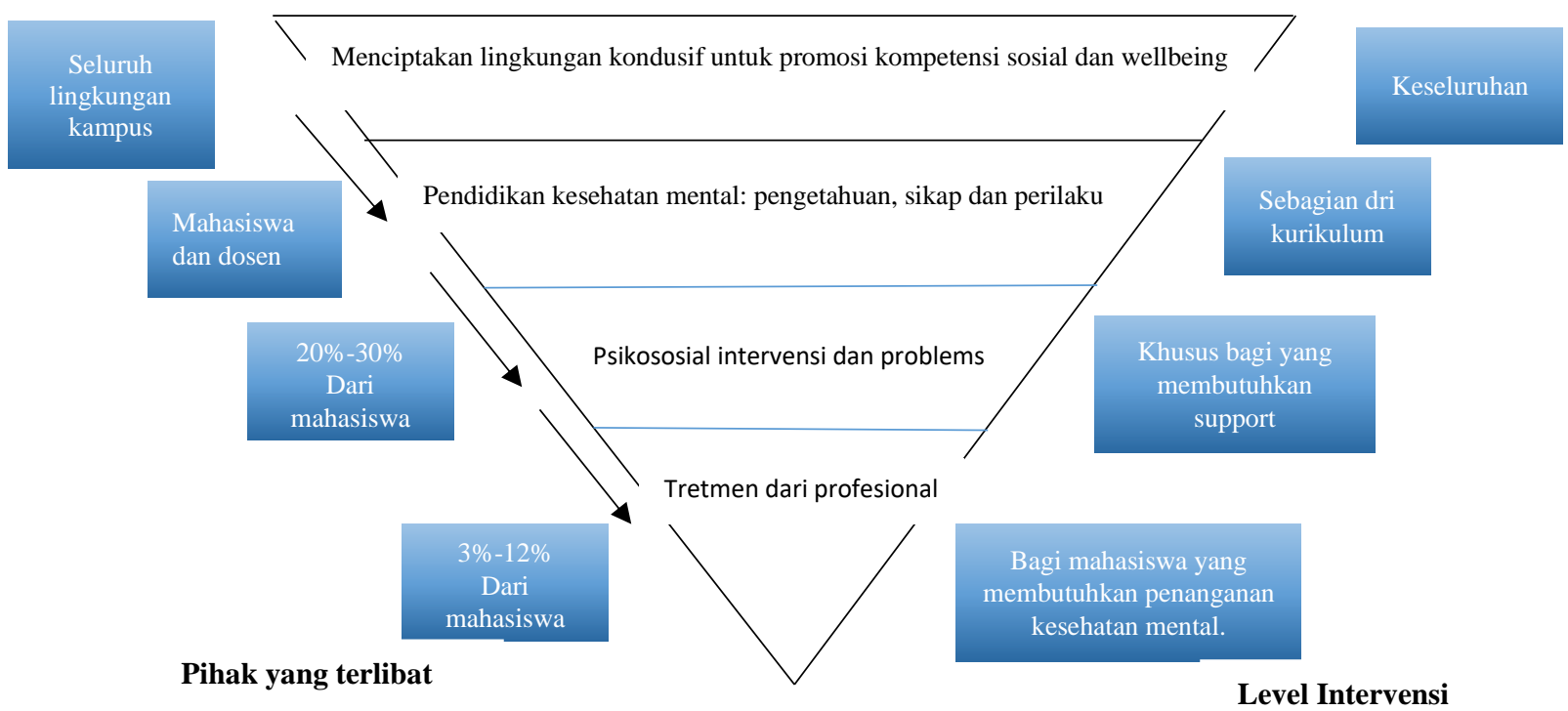

Gambar 3 menunjukkan adanya keterlibatan yang dapat mendukung tercapainya target program promosi kesehatan mental. Pihak yang terlibat meliputi pemimpim di lingkungan kampus hingga di tingkat mahasiswa yang memiliki risiko persoalan kesehatan mental. Model program promosi yang diharapkan akan menyentuh seluruh lapisan di lingkungan kampus. Sebagai awal mula untuk menggunggah kesadaran akan 
pentingnya pemahaman akan isu kesehatan mental (Karyani et al., 2016). Usulan rekomendasi dosen wali dari hasil penelitian ini juga dapat memberikan reward kepada dosen wali. Adanya perubahan kurikulum dengan menambahkan fungsi dan peran dosen wali dengan memberikan penghargaan tertentu sebagai apresiasi kepada dosen wali. Selain itu juga dapat memberikan semangat dan motivasi untuk dapat dengan secara optimal melayani kebutuhan mahasiswa yang mendukung kualitas kesehatan mentalnya.

\section{Kesimpulan}

Peran dosen wali sangatlah penting sebagai pendamping mahasiswa melalui masa transisi kehidupan yang penuh tantangan untuk mencapai kulitas pribadi yang positif dan mencapai kondisi kesehatan mental yang baik. Berdasarkan penelitian ini dosen wali mengkonfirmasi kebutuhan dan keinginan terhadap penyediaan layanan peningkatan kualitas kesehatan mental mahasiswa. Hal tersebut juga berkaitan sebagai upaya preventif dalam mewujudkan kondisi psikologis mahasiswa yang lebih baik selama masa studi hingga menjadi lulusan. Dan juga harapan adanya layanan untuk meningkatkan kompetensi mahasiswa yang berkaitan dengan wawasan penyesuaian dalam memasuki masa mahasiswa dan ketrampilan yang berhubungan dengan kesehatan mental.

Hasil penelitian menunjukkan bahwa dosen wali membutuhkan kegiatan peningkatan kompetensi dalam rangka mengoptimalisasi peran dan fungsinya yang telah diatur dalam kurikulum.. Hasil penelitian ini digunakan sebagai landasaran sistem layanan pendukung secara komprehensif. Sistem layanan pendukung sebagai layanan yang integratif mempermudah alur dan komunikasi dari departemen, mahasiswa, dosen (wali) dan orang tua. Oleh karena itu, desain strategi promosi kesehatan mental melibatkan seluruh stakeholder di lingkungan kampus termasuk melibatkan peran dosen wali dan mahasiswa secara umum. Secara praktis selanjutnya, diperlukan dukungan dan keterlibatan dari pemimpin di perguruan tinggi dalam rangka ikut melakukan penyesuaian kebijakan yang berpihak pada kualitas kesehatan mental mahasiswa.

\section{Saran}

Hasil penelitian ini masih dalam tahap awal karena jumlah partisipan yang terbatas, sehingga perlu dilakukan penelitian yang lebih mendalam dan melibatkan partisipan dalam jumlah lebih besar untuk memperkaya hasil penelitian sebagai dasar penentuan kebijakan kampus. Diharapkan strategi layanan peningkatan kualitas kesehatan mental di perguruan tinggi dapat direalisasikan dan diinternalisasi ke dalam kurikulum pendidikan. Selain itu, dalam hal keberhasilan penelitian kesehatan mental di perguruan tinggi sangat diperlukan sinergi dengan pihak-pihak terkait di kampus dalam mendukung terlaksananya penelitian terutama dalam pencapaian target partisipan yang diharapkan; karena tema kesehatan mental di kampus masih dianggap belum cukup populer. 


\section{Daftar Pustaka}

Chan, Z. C. Y. (2016). A qualitative study of freshmen's and academic advisors' perspectives on academic advising in nursing. Nurse Education in Practice, 18, 23-29. https://doi.org/10.1016/j.nepr.2016.02.010

Conley, C. S., Durlak, J. A., \& Dickson, D. A. (2013). An evaluative review of outcome research on universal mental health promotion and prevention programs for higher education students. Journal of American College Health, 61(5), 286-301. https://doi.org/10.1080/07448481.2013.802237

Douce, L. A., Keeling, R. P., Collins-eaglin, J., Kilmer, J. R., Olson, T. A., \& Sponsler, B. A. (2014). Primer on College Student Mental Health Authors.

Dunne, C., \& Somerset, M. (2004). Health promotion in university: What do students want? Health Education, 104(6), 360-370. https://doi.org/10.1108/09654280410564132

Hunt, J., \& Eisenberg, D. (2010). Mental Health Problems and Help-Seeking Behavior Among College Students. Journal of Adolescent Health, 46(1), 3-10. https://doi.org/10.1016/j.jadohealth.2009.08.008

Karyani, U. (2016). Designing School To Be A School Promote Mental Health. Jurnal Indigenous, 1(1), 4860.

Karyani, U., Paramastri, I., \& Ramdani, N. (2016). Riset Terkini Intervensi Berbasis Sekolah untuk Promosi Kesehatan Mental Siswa : Review Sistematis, 19-20.

Kermode, M., Herrman, H., Arole, R., White, J., Premkumar, R., \& Patel, V. (2007). Empowerment of women and mental health promotion: a qualitative study in rural Maharashtra , India, 10, 1-10. https://doi.org/10.1186/1471-2458-7-225

Macaskill, A. (2013). The mental health of university students in the United Kingdom. British Journal of Guidance and Counselling (Vol. 41). https://doi.org/10.1080/03069885.2012.743110

Marshall, L. \& Morris, C. (2015). Taking wellbeing forward in higher education.

Reilly, M. O., Svirydzenka, N., Adams, S., \& Dogra, N. (2018). Review of mental health promotion interventions in schools. Social Psychiatry and Psychiatric Epidemiology, 53(7), 647-662. https://doi.org/10.1007/s00127-018-1530-1

Smith, H., \& Myriam, F. (2013). Promoting youth mental health through the transition from high school Literature review and environmental scan, (April).

Susilowati, T. G., \& Hasanat, N. U. (2011). Pengaruh Terapi Menulis Pengalaman Emosional Terhadap Penurunan Depresi pada Mahasiswa Tahun Pertama, 38(1), 92-107.

Wenham, K. E., Valencia-Forrester, F., \& Backhaus, B. (2019). Make or break: the role and support needs of academic advisors in work-integrated learning courses. Higher Education Research and Development, O(0), 1-14. https://doi.org/10.1080/07294360.2019.1705254

WHO. (2004). Promoting Mental Health: Concepts, Emerging Evidence, Practice: Summary Report. Geneva, World Health Organization. Retrieved. Http://Www.Who.Int/Mental_Health/Evidence/En/Promoting_Mhh.Pdf, 68. https://doi.org/10.1111/j.1466-7657.2004.00268.x

Wojda-kornacka, J. (2016). What mental health promotion do university students need ?, 14(3), 53-72. https://doi.org/10.1515/pjap-2015-0062 